\title{
Effect of Divalent Metal Ions on Glucoamylase Activity of Glucoamylase Isolated from Aspergillus niger
}

Okwuenu PC, Agbo KU, Ezugwu AL, Eze SO and Chilaka FC

Department of Biochemistry, Faculty of Biological Sciences, University of Nigeria, Nsukka, Enugu State, Nigeria.

Corresponding author: Okwuenu PC, Department of Biochemistry, Faculty of Biological Sciences, University of Nigeria, Nsukka, Enugu State, Nigeria, Tel: +2348065251877; E-mail: prosperokwuenu@yahoo.com

Received date: Jan 06, 2017, Accepted date: Jan 28, 2017, Published date:Jan 31, 2017

Copyright: (C) 2017 Okwuenu PC, et al. This is an open-access article distributed under the terms of the Creative Commons Attribution License, which permits unrestricted use, distribution, and reproduction in any medium, provided the original author and source are credited.

\begin{abstract}
This study investigates the production of glucoamylase from Aspergillus niger in a submerged fermentation process using amylopectin fractionated from guinea corn starch as the carbon source. This work also studies the effect of a few metal ions $\left(\mathrm{Ca}^{2+}, \mathrm{Zn}^{2+}, \mathrm{Co}^{2+}, \mathrm{Fe}^{2+}, \mathrm{Mn}^{2+}\right.$ and $\left.\mathrm{Pb}^{2+}\right)$ concentration on the glucoamylase activity. A Fourteen day experimental study was carried out to determine the day of highest glucoamylase activity. Maximum glucoamylase activity was observed on day five of the submerged fermentation; hence, day five was mass produced. The specific activity for the crude enzyme was found to be $729.45 \mathrm{U} / \mathrm{mg}$. The crude enzyme was purified to the level of gel filtration (using sephadex G-100) via ammonium sulphate precipitation. Ammonium sulphate saturation of $70 \%$ was found suitable to precipitate the enzyme. After ammonium sulphate precipitation and gel filtration, the specific activities were found to be $65.98 \mathrm{U} / \mathrm{mg}$ and $180.52 \mathrm{U} / \mathrm{mg}$ respectively. The glucoamylase activity was enhanced by $2 \mathrm{mM}$ to $5 \mathrm{mM}$ of $\mathrm{Ca}^{2+}, \mathrm{Co}^{2+}, \mathrm{Fe}^{2+}, \mathrm{Mn}^{2+}$ and $\mathrm{Zn}^{2+}$ but $\mathrm{Pb}^{2+}$ had inhibitory effect on the enzyme. The Michaelis constant, $\mathrm{Km}$ and maximum velocity $\mathrm{Vmax}$ of the enzyme was obtained from the Lineweaver-Burk plot of initial velocity data at different substrate concentrations. They were found to be 770.75 $\mathrm{mg} / \mathrm{ml}$ and $2500 \mu \mathrm{mol} / \mathrm{min}$ respectively, when using cassava starch as substrate. The enzyme glucoamylase is known to have useful applications in food processing industries and fermentation biotechnology.
\end{abstract}

Keywords Glucoamylase; Enzyme; Aspergillus; Metal ions; Activity

\section{Introduction}

Glucoamylase (exo-1, 4-a-D-glucan-glucanohydrolase, EC 3.2.1.3) belongs to the most important catalytically active proteins having broad possibilities of technical use. It is an exo acting enzyme that yields $B$-D-glucose from the non-reducing chain ends of amylose and amylopectin by hydrolyzing $\alpha-1,4$ linkages in a stepwise manner [1]. It also hydrolyses $\alpha-1,6$ and the rare $\alpha-1,3$ linkages although at much slower rate [2]. Generally, amylases, (that is $\alpha$ - amylases, $\beta$-amylases and glucoamylase) can be produced either by submerged fermentation $(\mathrm{SmF})$ or solid state fermentation (SSF) procedures; however, the convectional amylase production is carried out by submerged fermentation [3] Glucoamylase production from microbial sources especially from Aspergillus niger is generally extracellular, and the enzyme can be recovered from culture filtrates. However, the extensive utilization of glucoamylase is obtained by using the fungus Aspergillus niger in enzyme production industries. Enzymes may require metal ions for their maximal catalytic activity and are termed as holoenzymes. Metals are responsible for right orientation of active site of holoenzymes. Metal binding to enzyme is one of the factors responsible for protein stabilization [4,5]. As a result of the important role of glucoamylase, it is highly desirable to increase or enhance the glucoamylase activity in other to improve its useful applications and utilization.

\section{Materials and methods}

\section{Chemicals}

Bovine serum albumin (BSA), Sephadex G-100 was purchase from Sigma Chemical Company Limited (USA). Folin-Ciocalteau was purchased from Sigma-Aldrich (USA). Ammonium Sulphate and Tris HCL salt were purchased from British Drug House (BDH) Chemicals Limited (USA). All other chemicals used in this work were of analytical grade and were obtained from reputable sources.

\section{Collection of plant material and processing of the starch}

Plant material (guinea corn seed and cassava tuber) was purchased from the Ogige market in Nsukka, Enugu state, Nigeria, and its starch was processed as described by Agboola [6].

\section{Fractionation of starch into amylopectin}

The starch obtained from guinea corn was fractionated according to the method of Sobukola and Aboderin [7].

\section{Isolation and identification of the glucoamylase producing fungi}

Glucoamylase producing fungi was isolated and stored according to the method described by Martin et al. [8] and the identification was carried out using the method of Barnett and Hunter [9]. 


\section{Fermentation broth for the enzyme production}

Submerged fermentation $(\mathrm{SmF})$ technique was employed using an Erlenmeyer flask containing $700 \mathrm{ml}$ of sterile cultivation medium optimized for glucoamylase with $2.1 \mathrm{~g}\left(\mathrm{NH}_{4}\right) 2 \mathrm{SO}_{3}, 4.2 \mathrm{~g} \mathrm{KH}_{2} \mathrm{PO}_{4}, 0.7 \mathrm{~g}$ $\mathrm{MgSO}_{4} .7 \mathrm{H}_{2} \mathrm{O}, 0.07 \mathrm{~g} \mathrm{FeSO}_{4}$ and $7 \mathrm{~g}$ amylopectin from guinea corn starch. From the $700 \mathrm{ml}$ of the sterile cultivation medium optimized for glucoamylase, $50 \mathrm{ml}$ each were poured into fourteen $250 \mathrm{ml}$ cornical flask, labelled day one to day fourteen. These flasks were stopped with aluminium foil and autoclaved at $121^{\circ} \mathrm{C}$ for $15 \mathrm{~min}$ to ensure sterility. For inoculation, three days old cultures were used to inoculate the flasks. In every sterile flask, two discs of the respective fungal isolates were added using a cork borer of diameter $10 \mathrm{~mm}$ and then plugged properly. The culture medium was incubated for fourteen days (14 days) at room temperature. For each day of harvest, a flask is selected serially from the flasks labelled day one to day fourteen and then, the mycelia biomass is separated by filtration, using a muslin cloth. Each day, a flask was selected according to their labels and the filtrate analyzed for glucoamylase activity and extracellular protein concentration through the fourteen days of fermentation.

\section{Mass production of enzyme}

After the fourteen days pilot submerged fermentation (SmF) studies, the day of peak glucoamylase activity was chosen for mass production of enzyme (that is, day five). Several Erlenmeyer flasks were used to produce two litres (that is, $2000 \mathrm{ml}$ ) of the enzyme. Harvesting was carried out on the day of peak glucoamylase enzyme activity. The medium composition that made up the $2000 \mathrm{ml}$ was

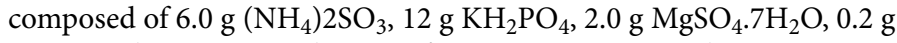
$\mathrm{FeSO}_{4}$ and $17.165 \mathrm{~g}$ amylopectin from guinea corn starch.

\section{Assay of glucoamylase}

Glucoamylase activity was assayed according to Miller [10]. It involves $0.5 \mathrm{ml}$ of the enzyme incubated with $0.5 \mathrm{ml}$ of $1 \%$ starch dissolved in $20 \mathrm{mM}$ sodium acetate buffer $\mathrm{pH} 5.0$ at $55^{\circ} \mathrm{C}$ for $20 \mathrm{~min}$. The released glucose was monitored by the addition of $1 \mathrm{ml}$ of $3,5-$ dinitrosalicyclic acid (DNSA), which also stopped the reaction, this was followed by boiling the mixture for $10 \mathrm{~min}$. Thereafter, $1 \mathrm{ml}$ of tartarate was added to stabilize the colour. The mixture was allowed to cool and the absorbance read spectrophotometrically at the wavelength of $540 \mathrm{~nm}$. One enzyme activity unit (U) was defined as the amount of enzyme releasing 1 micro mole of glucose from the substrate in one minute under standard assay condition. The concentration of the released glucose was estimated using a glucose standard curve.

\section{Assay of amylase}

Amylase activity was determined by the dinitrosalicyclic acid (DNSA) method as described by Bernfeld [11]. The amylase activity was assayed by incubating $0.5 \mathrm{ml}$ of the enzyme with $0.5 \mathrm{ml}$ of $1 \% \mathrm{w} / \mathrm{v}$ starch dissolved in $20 \mathrm{mM}$ sodium phosphate buffer $\mathrm{pH} 7.0$, at $55^{\circ} \mathrm{C}$ for $60 \mathrm{~min}$. The released reducing equivalent (maltose) was monitored by the addition of $1 \mathrm{ml}$ of 3, 5-dinitrosalicyclic acid (DNSA), which also stopped the reaction, this was then followed by boiling for $10 \mathrm{~min}$, thereafter, $1 \mathrm{ml}$ of tartarate was added to stabilize the colour, the mixture was then allowed to cool and the absorbance read spectrophotometrically at a wavelength of $600 \mathrm{~nm}$ against a blank, using UV-VIS (JENWAY 6405) spectrophotometer. The blank was made up of $0.5 \mathrm{ml}$ of the $1 \%$ starch dissolved in $20 \mathrm{mM}$ sodium phosphate buffer $\mathrm{pH} 7.0,1 \mathrm{ml}$ of 3, 5-dinitrosalicyclic acid and $1 \mathrm{ml}$ of tartarate. The same procedures used for the test solutions were used for the blank except that the blank lacked the enzyme solution. One unit of amylase activity was expressed as the amount of enzyme that releases one micro mole ( $\mu$ mole) of the reducing equivalent (maltose) per minute under assay conditions. Amylase activity was estimated by the amount of reducing equivalent (maltose) released during the hydrolysis of the starch.

\section{Protein determination}

Protein content of the enzyme was determined by the method of Lowry et al. [12], using Bovine Serum Albumin (BSA) as standard.

\section{Enzyme purification}

The crude glucoamylase was purified by using the following and important purification techniques

i) Ammonium Sulphate Precipitation.

ii) Gel Filtration

For the partial purification of the enzyme, the crude enzyme was submitted to fractionation by ammonium sulphate precipitation (70\% saturation). The precipitate was recovered by centrifugation at 4000 rpm for $10 \mathrm{~min}$ and the pellet dissolved in $20 \mathrm{mM}$ sodium acetate buffer $\mathrm{pH}$ 5.5. The suspension was further subjected to gel chromatography on sephadex G-100.

The active fractions were pooled. Enzyme activity and protein concentration were determined in the eluted solution at $540 \mathrm{~nm}$ and $280 \mathrm{~nm}$ respectively.

\section{Enzyme characterization}

The partially purified glucoamylase was subjected to characterization through kinetic studies by studying the effect of $\mathrm{pH}$, effect of temperature and effect of metalion $\left(\mathrm{Ca}^{2+}, \mathrm{Zn}^{2+}, \mathrm{Co}^{2+}, \mathrm{Fe}^{2+}\right.$, $\mathrm{Mn}^{2+}$ and $\mathrm{Pb}^{2+}$ ) concentration on the enzyme activity as described by Vijayaraghavan et al. [13].

\section{Optimum pH}

The optimum $\mathrm{pH}$ for enzyme activity was determined using $0.02 \mathrm{M}$ sodium acetate buffer $\mathrm{pH} 3.5$ to 5.5, phosphate buffer $\mathrm{pH} 6.0$ to 7.5 and Tris-HCl buffer $\mathrm{pH} 8.0$ to 10.0 at intervals of 0.5 , then, $0.5 \mathrm{ml}$ of gelatinized starch solution (1\%) was equilibrated with $1 \mathrm{ml}$ of the buffers $(20 \mathrm{mM})$ of respective pHs for $5 \mathrm{~min}$ at $37^{\circ} \mathrm{C} .0 .5 \mathrm{ml}$ of the enzyme was added and the reaction mixture was mixed properly and allowed to stand for $20 \mathrm{~min}$ at $50^{\circ} \mathrm{C}$. The glucoamylase activity was assayed as described above using starch as substrate

\section{Optimum temperature}

The optimum temperature for glucoamylase activity was determined by incubating the enzyme with gelatinized starch solution (1\%) at 30 to $80^{\circ} \mathrm{C}$ for $20 \mathrm{~min}$ at the predetermined optimal $\mathrm{pH}$. Glucoamylase activity was assayed as described above using starch as substrate.

\section{Effect of metal ions on glucoamylase activity}

Different concentrations ( $2 \mathrm{mM}, 3 \mathrm{mM}, 4 \mathrm{mM}$ and $5 \mathrm{mM}$ ) of metal salts $\left(\mathrm{CaCl}_{2}, \mathrm{MgCl}_{2}, \mathrm{MnCl}_{2}, \mathrm{FeCl}_{2}, \mathrm{ZnCl}_{2}\right.$ and $\left.\mathrm{PbCl}_{2}\right)$ were prepared in 
$20 \mathrm{mM}$ sodium acetate. Each of the reaction mixtures contained $0.5 \mathrm{ml}$ of enzyme solution, $0.5 \mathrm{ml}$ of $1 \%$ starch solution and $1 \mathrm{ml}$ of metal ion solutions $\left(\mathrm{Ca}^{2+}, \mathrm{Mg}^{2+}, \mathrm{Mn}^{2+}, \mathrm{Fe}^{2+}, \mathrm{Zn}^{2+}\right.$ and $\left.\mathrm{Pb}^{2+}\right)$. The mixtures were incubated for $20 \mathrm{~min}$ at the predetermined optimal $\mathrm{pH}$ and optimal temperatures. The control was carried out without metal ions.

\section{Results and Disscussion}

\section{Amylopectin yield}

Amylopectin fractionated from guinea corn starch was used as the carbon source for the extraction of glucoamylase from Aspergillus niger. Table 1 summarizes that amylopectin fractionated from the guinea corn starch gave a yield of $62.4 \%$ at temperature of $100^{\circ} \mathrm{C}$ and extraction time of $60 \mathrm{~min}$, using the method described by Sobukola and Aboderin [7]. Mahsa et al. [14] discovered during the partial fractionation of wheat starch using zonal ultracentrifugation that in cereal starches, they is approximately $25 \%$ amylose and $75 \%$ amylopectin. Balole and Legwaila [15] studied the starch components of guinea corn and discovered that the guinea corn starch has approximately $70-80 \%$ amylopectin content. Lawal et al. [16,17], in the study on the functional properties of amylopectin and amylose fractions isolated from bambarra groundnut starch, discovered that the amylose and amylopectin content of the bambarra groundnut starch were $75 \%$ and $11 \%$ respectively.

\begin{tabular}{|c|c|c|}
\hline $\begin{array}{c}\text { Weight of the Guinea corn } \\
\text { starch } \mathbf{( g )}\end{array}$ & $\begin{array}{c}\text { Weight of the dried } \\
\text { amylopectin } \mathbf{( g )}\end{array}$ & $\begin{array}{c}\text { Percentage yield } \\
\mathbf{( \% )}\end{array}$ \\
\hline 20 & 12.48 & 62.4 \\
\hline
\end{tabular}

Table 1: Percentage yield of the amylopectin from guinea corn starch

This high amylopectin content could be responsible for easy gelatinization, as the high amylopectin content of starch aids starch gelatinization Okporie et al. [16].

\section{Preliminary studies}

Figure 1 shows the glucoamylase activities during the experimental study of fourteen (14) days (1-14 days). High glucoamylase activity were obtained on the fifth (5th) day $(319.059 \mu \mathrm{mol} / \mathrm{min})$ and on the twelfth (12th) day $(299.5626 \mu \mathrm{mol} / \mathrm{min})$, when cassava starch was used as the substrate, while the least activity was on the fourteen (14th) day $(12.7551 \mu \mathrm{mol} / \mathrm{min})$. Glucoamylase activity increased from day 3 to day 5 and from day 11 to day 12, with maximum levels of glucoamylase activity obtained at day five (5) and day twelve (12) of submerged fermentation. Similar observations were reported by Fabiana et al. [18], in their report; the maximum glucoamylase activity was achieved on day 3 of the submerged fermentation. Also, the decrease in glucoamylase production from day 6 to day 10 and from day 12 to day 14 could be attributed to high glucose concentration obtained by the microorganism, Christiane et al. [19], in their research, reported that glucoamylase production by Aspergillus niger is repressed due to high glucose concentration in the microorganism, nevertheless, when glucose concentration decreases in the microorganism, the microorganism ( Aspergillus niger) then starts to produce glucoamylase again, to hydrolyze the substrate (in this case, amylopectin from guinea corn starch) to produce more glucose due to increased production of glucoamylase, as observed from the peaks obtained.

Figure 1 also shows a -amylase activity during the pilot study of fourteen (14) days (1-14 days) when cassava starch was used as substrate. High $a$-amylase activities were obtained on the fifth (5th) day $(103.290 \mu \mathrm{mol} / \mathrm{min})$ and on the twelfth $(12 \mathrm{th})$ day $(166.666 \mu \mathrm{mol} /$ min), while the least activity was on the fourteen (14th) day (75.431 $\mu \mathrm{mol} / \mathrm{min}$ ). Kshipra et al. [20], in their work, reported that other amylolytic enzymes particularly $a$-amylase is most likely to be concomitantly produced with glucoamylase. Figure 1 also shows, protein concentration of the filtrate for an incubation period of fourteen days (14) days (1-14 days). The highest protein concentration was obtained on the fifth $(5 \mathrm{th})$ day $(13.2826 \mathrm{mg} / \mathrm{ml})$ while the least protein concentration $(0.7391 \mathrm{mg} / \mathrm{ml})$ was obtained on the first (1st) day. The protein production observed in this study could be due to an array of proteinous metabolites generated during the growth and metabolism of the microorganism. The day of highest glucoamylase activity (that is, day five) was then mass produced.

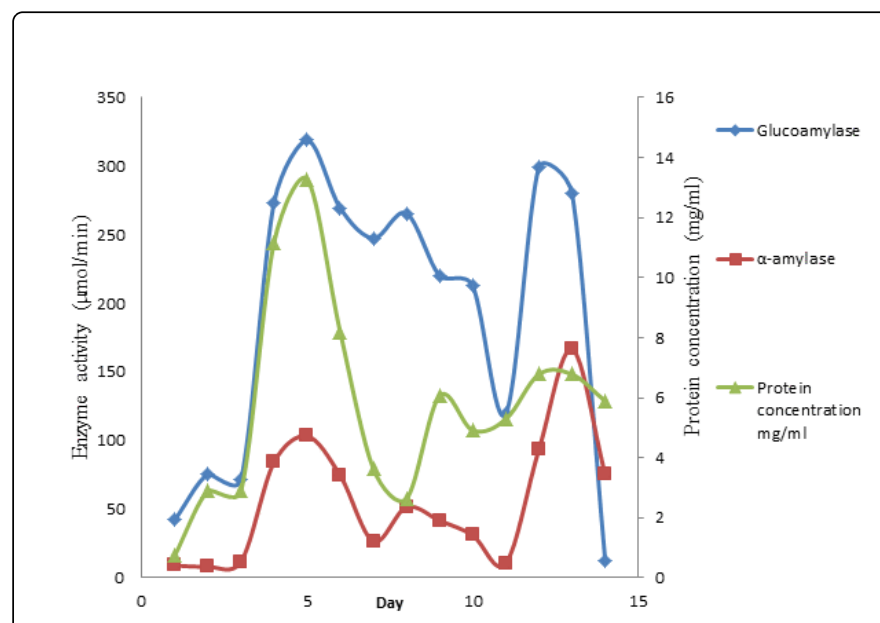

Figure 1: Progress curve of glucoamylase activity, alpha amylase activity and protein concentration on various days of incubation.

\section{Purification studies}

The partial purification of glucoamylase harvested on day five of the submerged fermentation is summarized in Table 2.

\begin{tabular}{|c|c|c|c|c|c|c|c|c|}
\hline Enzyme & Volume (ml) & $\begin{array}{c}\text { Protein } \\
\mathbf{( m g / m l )}\end{array}$ & Total Protien & Activity $(\boldsymbol{\mu m o l} / \mathbf{m i n})$ & Total activity & $\begin{array}{c}\text { Specific } \\
\mathbf{( U / m g )}\end{array}$ & Purification Fold & \% Yield \\
\hline Crude & 1000 & 0.455 & 455 & 331.9 & 331900 & 729.45 & 1 \\
\hline$(\mathrm{NH} 4) 2 \mathrm{SO} 4$ & 280 & 1.662 & 465.36 & 109.67 & 30707.6 & 65.98 & 0.1 \\
\hline
\end{tabular}


Citation: Okwuenu PC, Agbo KU, Ezugwu AL, Eze SO, Chilaka FC (2017) Effect of Divalent Metal lons on Glucoamylase Activity of Glucoamylase Isolated from Aspergillus niger. Ferment Technol 6: 141. doi:10.4172/2167-7972.1000141

Page 4 of 6

\begin{tabular}{|l|l|l|l|l|l|l|l|l|}
\hline Gel filtration & 30 & 0.134 & 4.02 & 24.19 & 725.7 & 180.52 & 2.7 & 2.36 \\
\hline
\end{tabular}

Table 2: Purification table for glucoamylase harvested on day five of the submerged fermentation

In this study, maximum glucoamylase activity was obtained with $70 \%$ of ammonium sulphate $\left(\mathrm{NH}_{4}\right) 2 \mathrm{SO}_{4}$ concentration and the enzyme activity was found to be $109.67 \mu \mathrm{mole} / \mathrm{min}$ and a specific activity of $65.98 \mathrm{U} / \mathrm{mg}$. After ammonium sulphate purification, gel filtration was carried out to purify more glucoamylase. From the elution profile of the gel chromatography on sephadex G-100 (Figure 2 ), peaks showing glucoamylase activity were obtained, these peaks were pooled together and enzyme activity as well as protein concentration was assayed. In this study, after the gel filtration, glucoamylase activity was obtained to be $24.19 \mu \mathrm{mole} / \mathrm{min}$, with a specific activity of $180.52 \mathrm{U} / \mathrm{mg}$. The decrease in the enzyme activity after each purification step could be attributed to the removal of impurities such as other proteins which enhances the enzyme activity as the enzyme might have lost some cofactors or ions that it needs for its activity. In similar manner, decrease in specific activity of the enzymes after ammonium sulphate precipitation may be attributed to the precipitation of other unwanted proteins at different percentages of the ammonium salt during the salting out process. Sangeeta et al., [21] reported similar result during the extraction and purification of glucoamylase and protease produced by Aspergillus awamori in Single-Stage fermentation. Also, the increase in specific activities for both enzymes after gel filtration could be ascribed to the fact that for a purification procedure to be successful, the specific activity of the desired enzyme must be greater after the purification procedure than as it was before Lukong et al., [22]. The percentage yield of the enzyme was $100 \%, 9.25 \%$ and $2.36 \%$ for crude, precipitate and gel filtration chromatography respectively.

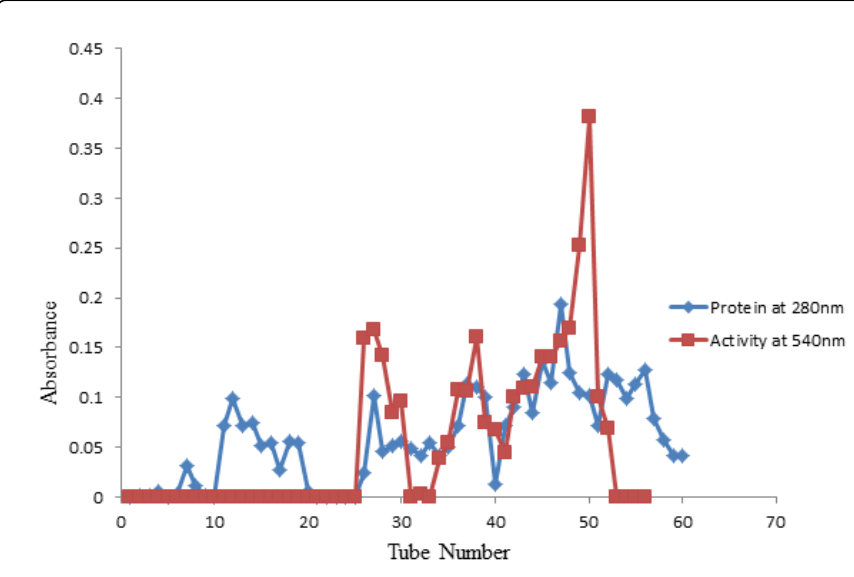

Figure 2: Elution profile of glucoamylase (harvested on day five of submerged fermentation) during gel filtration on a $120 \mathrm{ml}$ volume of sephadex G-100 packed into a column (75 by $2.0 \mathrm{~cm}$ ) and equilibrated with $50 \mathrm{mM}$ sodium acetate buffer, $\mathrm{pH}$ 5.0. A volume of $5 \mathrm{ml}$ of 60 fractions were collected at an elution rate of $5 \mathrm{ml}$ per $20 \mathrm{~min}$. Glucoamylase activity and protein determination was assayed in each of the fractions collected.

\section{Characterization of glucoamylase}

Optimum pH: The effect of $\mathrm{pH}$ on the glucoamylase activity is as shown in Figure 3. As the $\mathrm{pH}$ increased, the activity of glucoamylase also increased until optimum $\mathrm{pH}$ was obtained at 7.5 with an enzyme activity of $67.416 \mu \mathrm{mol} / \mathrm{min}$ when cassava starch was used as the substrate, then the activity of the enzyme decreased till $\mathrm{pH} 11$. James and Lee [23] reported that the range of glucoamylase $\mathrm{pH}$ is between 3.7 and 7.4. Nahar et al., [24] reported that the optimum $\mathrm{pH}$ range of glucoamylase varies from 4.5 to 5.5 with stability at $\mathrm{pH}$ 7.0. Changes in $\mathrm{pH}$ can change the shape of the active site in an enzyme. Extremely high or low $\mathrm{pH}$ concentrations usually result in complete loss of enzyme activity due to denaturation Helms et al. [25].

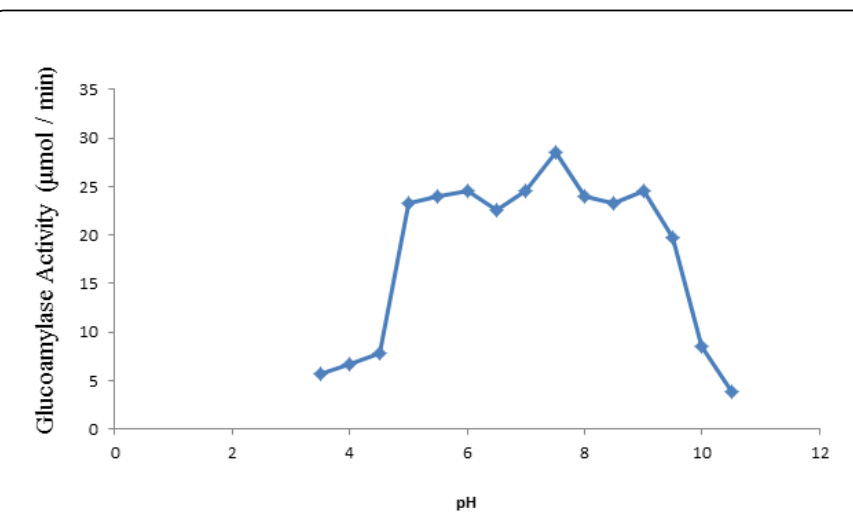

Figure 3: Effect of $\mathrm{pH}$ on glucoamylase activity for glucoamylase harvested on day five of submerged fermentation, $20 \mathrm{mM}$ sodium acetate buffer $\mathrm{pH} 3.5$ to $5.5,20 \mathrm{mM}$ phosphate buffer $\mathrm{pH} 6.0$ to 7.5 and $20 \mathrm{mM}$ Tris- $\mathrm{HCl}$ buffer $\mathrm{pH} 8.0$ to 10.0 , at intervals of 0.5 was used in the assay and an optimum pH 7.5 was obtained.

\section{Optimum temperature}

The optimum temperature for glucoamylase harvested on day five was $50^{\circ} \mathrm{C}$, with glucoamylase activity of $67.055 \mu \mathrm{mole} / \mathrm{min}$ as shown in Figure 4; this was in accordance with Siddhartha et al., [26] who reported that temperature optima for glucoamylases are generally in the range of $45^{\circ} \mathrm{C}$ to $60^{\circ} \mathrm{C}$. Sarojin et al., (2012) also reported that optimum glucoamylase activity was obtained at $45^{\circ} \mathrm{C}$. All enzymes have an optimal temperature at which reaction rates go fastest without denaturation of the enzyme Campbell and Reece, [27]. 
Page 5 of 6

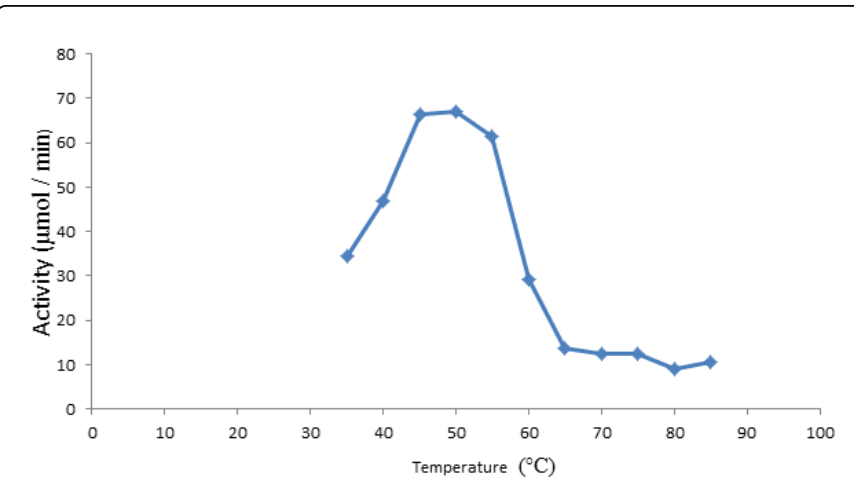

Figure 4: Effect of temperature on glucoamylase activity for glucoamylase harvested on day five of submerged fermentation. Activity was assayed in $20 \mathrm{mM}$ phosphate buffer $\mathrm{pH} 7.5$ from $30 \mathrm{pbel}^{\circ} \mathrm{C}$ to $90^{\circ} \mathrm{C}$ after incubation for $20 \mathrm{~min}$ and coupling with DNS (3, 5- dinitrosalicyclic acid). Optimum temperature of $50{ }^{\circ} \mathrm{C}$ was obtained.

\section{Effect of metal ion concentration}

Figure 5 summarizes the effect of metal ion concentration on glucoamylase activity. $\mathrm{Ca}^{2+}, \mathrm{Zn}^{2+}, \mathrm{Co}^{2+}, \mathrm{Fe}^{2+}$ and $\mathrm{Mn}^{2+}$ ions all enhanced the activity of glucoamylase, while $\mathrm{Pb}^{2+}$ inhibited the glucoamylase activity.

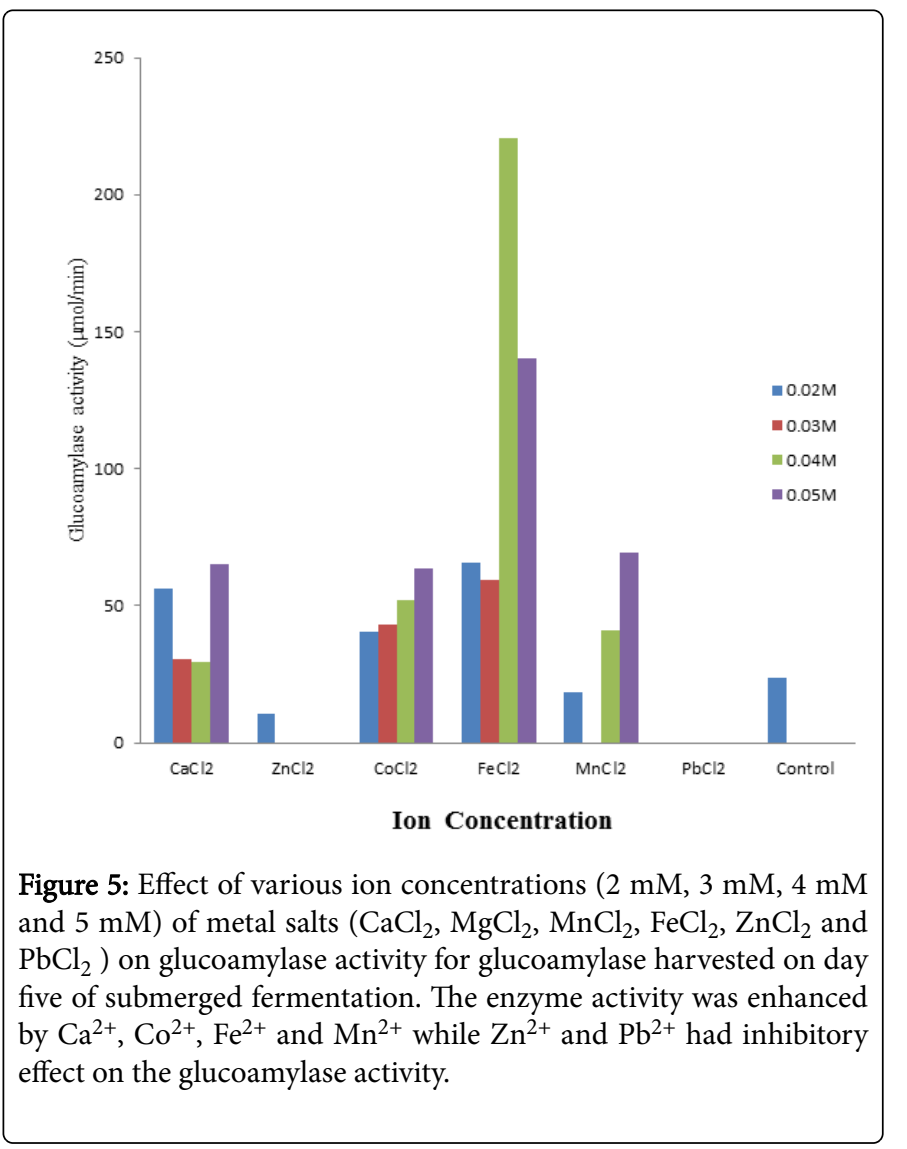

The concentrations of the $\mathrm{Fe}^{2+}$ solutions gave the highest activity of glucoamylase as $0.02 \mathrm{M}, 0.03 \mathrm{M}, 0.04 \mathrm{M}$ and $0.05 \mathrm{M}$ showed an activity of $65.597,59.584,220.84$ and $140.488 \mu \mathrm{mol} / \mathrm{min}$ respectively. All the concentrations of the lead ion used complete inhibition of the enzyme. Vivian et al., [28] reports the activation of glucoamylase from Aspergillus phoenicis by manganese $\left(\mathrm{Mn}^{2+}\right)$ and calcium $\left(\mathrm{Ca}^{2+}\right)$ ions. The increase in glucoamylase activity caused by these metal ions $\mathrm{C}^{2+}$, $\mathrm{Zn}^{2+}, \mathrm{Co}^{2+}, \mathrm{Fe}^{2+}$ and $\mathrm{Mn}^{2+}$ ions) could be attributed to the ability of these metals ions to serve as an electron donor or Lewis acid as they participate directly in the catalytic mechanism of the enzyme. Similarly, the decrease in the enzyme activity caused by the lead ion could be due to the interaction of the lead ion with the amino acid residues of the catalytic sites that also serves as electron donors in the catalytic site of the enzyme, as most heavy metals interfere strongly with amino acid residues of the catalytic site of enzymes [29].

\section{Conclusion}

In the light of above result, it therefore suggests that the enzyme glucoamylase can be enhanced by the use of some metal ions (such as $\mathrm{Ca}^{2+}, \mathrm{Co}^{2+}, \mathrm{Fe}^{2+}$ and $\mathrm{Mn}^{2+}$ ) to bring about an improved use of the enzyme. Glucoamylase is found useful in industries where starch hydrolysis is required, such as, the food processing, textile industries, brewery industries and in fermentation biotechnology

\section{Contributions}

Prosper secured the samples used in this research work, carried out the research work jointly and together with Arinze, under the supervision of Chilaka and Eze, while Kenneth read and arranged the manuscript of this work.

\section{Acknowledgement}

Enormous gratitude and appreciation to Professor F.C. Chilaka, $\mathrm{Mr}$ and Mrs Kenneth Okwuenu, for their financial assistance and help towards the funding of this research. We are also grateful to authors, editors, publisher of all articles, journals and books from which the literature of this research work has been discussed.

\section{References}

1. Bhatti HN, Asma Z, Rakhshanda N, Munir AS, Muhammad HR, (2005) Effect of copper ions on thermal stability of glucoamylase from Fusarium sp. Int J Agri Biol 4: 585-587.

2. Abdalwahab SA, Ibrahim SA, Dawood ES (2012) Culture condition for the production of glucoamylase enzyme by different isolates of Aspergillus spices. Intern Food Research J 19: 1261-1266.

3. Radha K, Srivastava AK, Ramaswamy NK, Suprasanna P, Souza SF (2012) Banana peel as substrate for alpha amylase production using Aspergillus niger NCIM 616 and process optimization. Ind J Biotechnol 11:314-319.

4. Sarojini R, Deepika K, Rangabhashiyam S (2012) Production, characterization, kinetic studies of glucoamylase through solid-state fermentation by Aspergillus niger using agricultural residues as substrate. Int J Curr Rsrch 4: 198-201.

5. Kellis J, Todd R, Arnold F (1991) Protein stabilization by engineered metal chelation. Biotechnology 9: 994-995

6. Agboola SO, Akingbala JO, Oguntimi GB (1990) Processing of cassava starch for adhesives production. Starch/Stakes 42: 12-15.

7. Sobukola, OP, Aboderin AT (2012) Studies on some properties of starches from three Mucuna species. International Food Research Journal 19: 913-921. 
Citation: Okwuenu PC, Agbo KU, Ezugwu AL, Eze SO, Chilaka FC (2017) Effect of Divalent Metal lons on Glucoamylase Activity of Glucoamylase Isolated from Aspergillus niger. Ferment Technol 6: 141. doi:10.4172/2167-7972.1000141

Page 6 of 6

8. Martin N, de Souza SR, da Silva R, Gomes E (2004) Pectinase production of fungal strains in solid-state fermentation using agro industrial bio product. Brazilian Archives of Biology and Technology 47: 813-819.

9. Barnett H, Hunter B (1972) Illustrated General of Imperfect Fungi.3rd edn Burgess, Minneapolis, Minnesota, USA. pp 20-130.

10. Miller GL (1959) Use of dinitrosalicyclic acid reagent for determination of reducing sugar. Analytical Chemistry 31: 426-428.

11. Bernfeld P (1951) Enzyme of starch degradation and synthesis. In: Advances in Enzymology. Biochemistry 28: 61-68.

12. Lowry OH, Rosebrough NJ, Farr AL, Randall RJ (1951) Protein measurement with folin phenol reagent. Journal of Biological Chemistry 193: $265-275$.

13. Vijayaraghavan P, Remya CS, Prakash SG (2011) Production of aAmylase by Rhizopus microsporus using Agricultural By product in solid state fermentation. Research Journal of Microbiology 6: 366-375.

14. Mahsa M, Arthur JR, Martin C, Sandra EH, Stephen EH (2003) Partial fractionation of wheat starch amylose and amylopectin using zonal ultracentrifugation. Carbohydrate Polymers 52: 269-274.

15. Balole TV, Legwaila GM, (2006) Cereals and pulses. Backhuys Publishers, Wageningen: 130-136.

16. Okporie EO, Chukwu SC, Onyishi GC, Ekwu LG (2014) Increase in protein, oil, amylose and amylopectin contents of two populations of maize (Zea Mays L.) after two cycles of reciprocal recurrent selection. J Agric Veter Sci 6: 2319-2372.

17. Lawal OS, Adebowale KO, Oderinde RA (2004) Functional properties of amylopectin and amylose fractions isolated from bambarra groundnut (Voandzeia subterranean) starch. Afr J Biotechnol 3: 399-404.

18. Fabiana CP, Eleni G, Roberto D (2008) Production and characterization of glucoamylase from fungus Aspergillus awamori expressed in yeast Saccharomyces. Brazilian J Microbiol 39: 108-114.

19. Christiane TS, Alex,V, Lopes M, Jorge L, Ricardo AA, Mareci M (2011) Biochemical characterization of a glucoamylase from Aspergillus niger produced by solid state fermentation. Brazilian Archieve of Biology and Technology 54: 1516- 8913.

20. Kshipra B, Deshmukh SA, Taur MN, Cherekar M (2011) Process optimization, purification and characterization of glucoamylase from different Sorghum varieties. Journal of Chemical and Pharmaceutical Research, 3: 732-737.

21. Sangeeta N, Suneel G, Rintu B (2011) Extraction and purification of glucoamylase and protease produced by Aspergillus awamori in single stage fermentation. Fod Technol Biotechnol 49: 310-315.

22. Lukong B, Awah F, Nwuke C, Fobellah A (2007) Protein Isolation, Purification and Estimation. In: Introduction to Protein Science, Osprey publication centre, Owerri. pp 55-56.

23. James JA, Lee BH (1997) Glucoamylases: microbial sources, industrial applications and molecular biology-A review. Journal of Food Biochemistry 21: 1-52.

24. Nahar S, Hossain F, Feroza B, Halim MA (2008) Production of glucoamylase by Rhizopus species in liquid culture. Pakistan Journal of Botany 40: 1693-1698.

25. Helms D, Helms C, Cummings J, Wilson J (1998) Biology in the Laboratory, 3rd edn New York, Freeman Publishing pp. 9: 1-8.

26. Siddhartha MK, Chandana ML, Sridevi V, Manasa M (2012) Glucoamylases: types, microbial sources and potential applications-A review. Int J Sci Inn Disc 2: 74-83.

27. Campbell N, Reece (2002) Biology, Don O'Neal, 6th edn. Benjamin Cummings Publishing, Menlo Park, California: 300-340.

28. Vivian MB, Thiago MP, Fernanda DA, Joao AJ, Maria de Lourdes T (2014) A novel glucoamylase activated by manganese and calcium produced in submerged fermentation by Aspergillus phoenicis. J Basic Microbiol 54: 333-339.

29. Riordan JF (1977) The role of metals in enzyme. Annual Clinical Laboratory Science 7: 119-129. 